\title{
Improvement of Trip Attraction Model in Surabaya by Considering Geographical Weighting of City Centre Activity Function
}

\author{
W Herijanto ${ }^{\mathrm{a}}$, I B Mochtar ${ }^{\mathrm{a}}$, A Wicaksono ${ }^{\mathrm{b}}$ \\ ${ }^{a}$ Department of Civil Engineering, Institut Teknologi Sepuluh Nopember, Surabaya, 60111, Indonesia \\ E-mail: herijanto@ce.its.ac.id; indramochtar.mochtar@gmail.com \\ ${ }^{b}$ Department of Civil Engineering, Brawijaya University, Malang, 65145, Indonesia \\ E-mail: wicaksono68@ub.ac.id
}

\begin{abstract}
It is challenging to have a trip attraction model that fits Surabaya's surveyed data due to unclear city centre structure. These include the centrum of concentric, corridors of sectoral, or several centres of multiple-nuclei structures. Also, the layout of residential areas has unconventional patterns. This is because the planned housing development area is wrongly inserted on kampong and sometimes lies in city centre. This paper examines the influence of single-centre districts, corridors, or multiple suburb centre structures on trip attraction. The analysis was conducted using origin-destination data from the household interview survey by The Transportation Board of Surabaya and several houses digitized from a relevant year's satellite image. The distance and position information was taken from the Google Earth application. The zonal analysis trip attraction model based on the sub-district zoning system was analysed using fixed trip production data and simulated independent variables. The independent variables included the zonal activity areas such as shops, offices, and industries in sub-district, while the dependent variables consisted of the straight distances from the sub-district to city centres. Several models were tested based on the dependent and independent variables. The results show that the combined zonal activity area and spatial variables have a stronger influence on zonal trip attraction than the conventional model using zonal labor and student variable, mainly based on the urban geographical pattern.
\end{abstract}

Keywords - transportation; trip attraction; Surabaya; concentric; sector; multiple-nuclei.

\section{INTRODUCTION}

The trips attracted by morning activities are vital in transportation planning since the influence the government's infrastructural implementation. The common variables used to predict zonal trip attractions are jobs and school capacities. Data on jobs and schools are readily available in many forms. Previously, other potential variables, such as building floor areas were difficult to be counted, hence neglected.

The distance between residential areas and activity centres also influences the number of trips attracted by zones [1]. Also, the city's distance, based on the CBD plan, influences trip attraction [2]. Therefore, the consideration of these factors is vital for city trip attraction. Sources of satellite images are commonly used in viewing activity centres in the city. An example is Google Earth, which is equipped with measuring tools [3].

The positions of activity centres and residential zones in an urban structure influence zonal trip attraction, especially the concentric, sectoral or multiple-nuclei structure, as mentioned in planning theory. In developing countries, however, poor urban planning results in inappropriate city layouts.

Current studies on trip attraction models cover a wide range of analyses. In most cases, however, conventional approaches are used, resulting in information that is difficult to interpret, such as socio-economic data. Furthermore, trip generation models ignore certain information, such as geographic position and spatial data. For instance, a study conducted in India used conventional methods and land-use area data to examine the trip attraction of the commercial mid-size town of Kerala [4]. Other studies employ the Artificial Neural Network-based approach for a trip attraction model [5].

\section{MATERIAL AND METHOD}

\section{A. Location}

Surabaya is a prominent city in East Java Province of Indonesia, situated in South-East Asia (Fig. 1). It covers 351 $\mathrm{km} 2$, with a population of more than 3 million inhabitants in 2018 (2.9 million in 2011). 
The city is divided into 31 administrative subdistricts (Fig. 2). A dense area's planning strategy in one of Surabaya city centres shows the mixed complexity of the old city area [8]. However, several areas are considered activity centres in slightly varying degrees, as shown in Fig. 3.

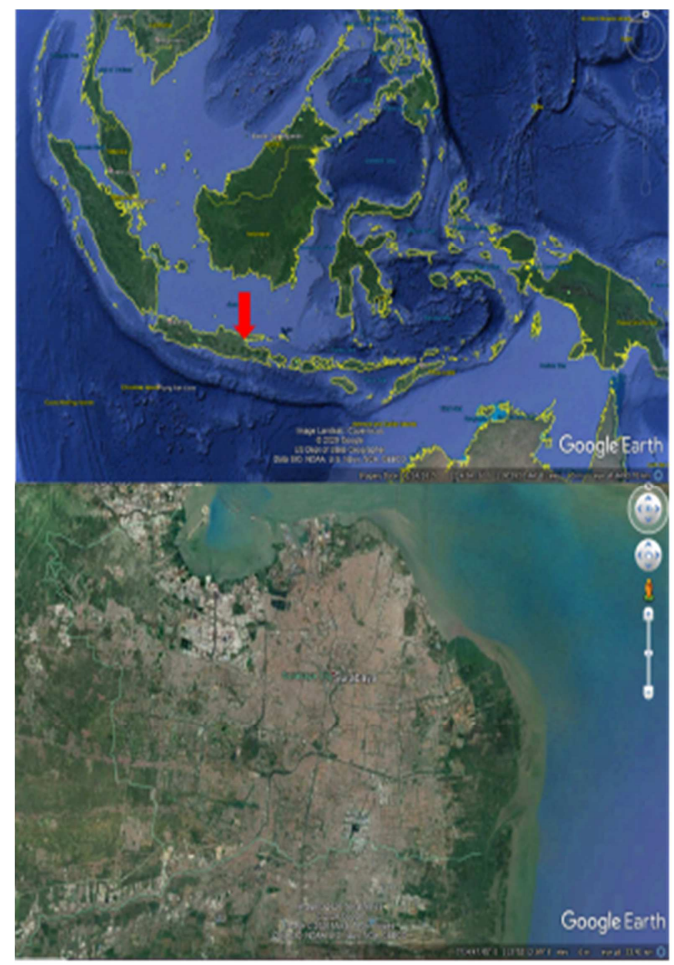

Fig. 1 Location and Surabaya city of Indonesia (top) [6] and the city (bottom) [7]

There is an old town in Surabaya, functioning as a regional trading centre. However, several other places are currently serving as trading centres with many activities. A new city centre began with retail businesses about 40 years ago, although many places around it have since attracted more visitors. There is several shopping centres in the west, east, and south of Surabaya. Therefore, solving the problem of trip attraction of Surabaya city requires several approaches.

A weak planning and development regulation of the city makes its centre to be unclearly defined. It is common for a smaller city to have a centrum, or several developed new centres, forming a monocentric or polycentric city [9].

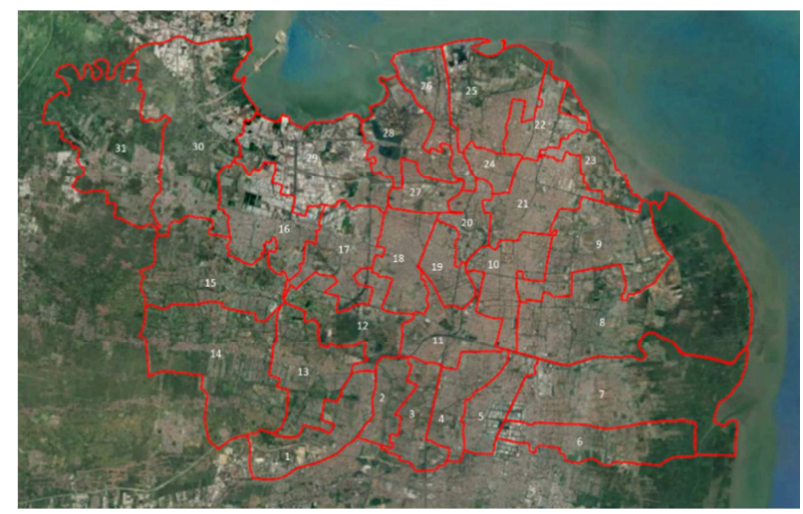

Fig. 2 Subdistrict administration in Surabaya (background [7])

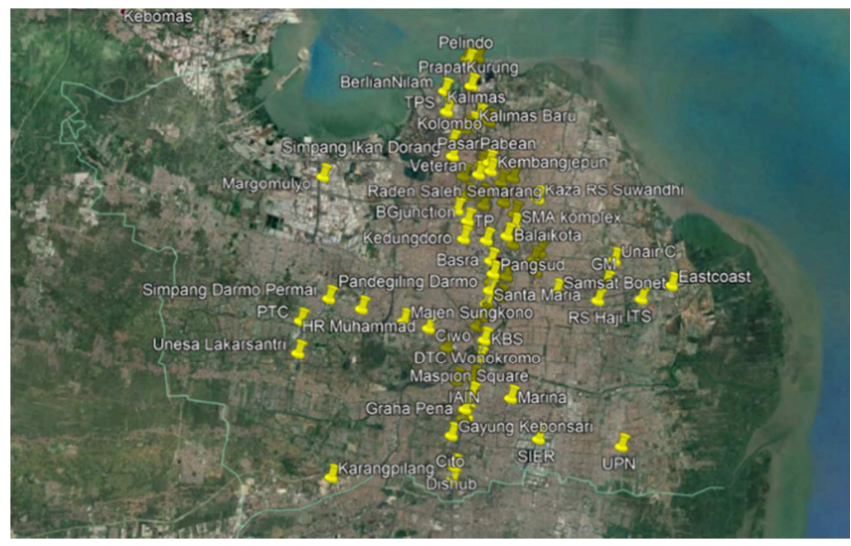

Fig. 3 Activity centres spreading in Surabaya (background [7])

Trip data was collected through the Surabaya home interview survey, conducted in 2011 [10]. It is currently the latest data available. The data on housing and the average distance between residential areas and city centre distance was collected by measurements using Google Earth.

\section{B. City Centres Definition}

City centres have structures that are theoretically classified as a concentric, sector and multiple-nuclei models. The concentric model is also known as the Burgess Model or the core frame model [11]. Sector model is referred to as Hoyt Model [12], while the multiple-nuclei model is known as Hariss-Ullman Model [13]. There is an airport $5 \mathrm{~km}$ outside of the city border. However, an aerotropolis concept does not shape the city structure yet [14].

\section{Data for Geographical and Spatial Variables}

A trip attraction model is categorized as a zonal base or land-use function base. The common variable for zonal analysis is labour and school capacity. This study explored other variables with a potentially high influence on trip attraction from the Google Earth application. A digitation on Google Earth combined with TCX converter software produced a set of digitized coordinates. Therefore, the floor area data of some functions in activity centres were prepared in a spreadsheet of Microsoft Excel for Office 365. Data compilation included zonal trip data and spatial data, which are average distances between residential and centres, as shown in Table 1.

Excel software calculates mathematical and numerical analysis and statistical operations once the data is prepared in Tools in Excel spreadsheets. For instance, straight distance is a calculation from the digitized attraction centre coordinates to the average digitized housing coordinate of every zone couple.

\section{Trip Atrraction Models Considering Geographical Weighting}

Spatial non-stationary local conditions are inserted in a more global equation using geographical weighting methods, such as in regression or linear models [16]. Combining local and global variables gives a better result, such as bikesharing trip production and attraction [17].

In the transportation field, the model is developed based on numerical analysis instead of the statistical approach, as seen in the double-constrained gravity model calibration [18]. 
This approach is useful for inserting geographical variables, especially in calculating weighted-variable. Trip attraction model is enhanced using geographical variables, including location effect of residence area inside or outside the city centre. The average distance from the activity centre, in this case, is also treated as geographical variables.

The Generalized Reduced Gradient Nonlinear method is beneficial in this case [19]. Excel Solver subroutine in Microsoft Excel for Office 365 works based on 3 options, including the GRG nonlinear. This option is based on Generalized Reduced Gradient methods, an algorithm for solving nonlinear general structure's nonlinear programs. It is powerful in handling these problems. Iteration stops when then the relative value is less than 0.0001 for the last 5 iterations.

\section{E. Calibration}

There are some statistical methods of comparing the sets of a modeled trip with surveyed trip distributions independent of each other. For instance, the chi-square calculation between modeled and observed trips $(\chi 2)$ is mentioned [20] and reviewed [21]. The formula is:

$$
\chi^{2}=\sum \frac{\left(T_{j}-T_{j}^{*}\right)^{2}}{T_{j}^{*}}
$$

Where:

$\mathrm{Tj}=$ observed trip attraction value of zone $\mathrm{j}$

$\mathrm{T} * \mathrm{j}=$ modelled trip attraction value of zone $\mathrm{j}$

\section{RESULTS AND DISCUSSION}

\section{A. Geographical Weighting}

This research built trip attraction models using digitized data of floor areas of different functions, such as street shopping, office and bank, school and university, industry and warehouse, and large shopping malls. The research also utilized the distance of residential to the city centre. Since Surabaya's city centre is somehow loosely defined, 3 types of urban forms were incorporated in several models, including the centre of concentric, corridors of the sector, and satellites of multiple-nuclei forms. Activity functions within and outside the 3 centres were weighted in the models and distance from city centres to residential. The models utilized linear and nonlinear approaches.

\section{B. Trip Atrraction without Considering Geographical Weighting and Spatial Variable}

Trip attraction model used zonal variables as a street shopping place, office and bank, school and university, industry and warehouse, and large shopping mall. Considering distance as spatial variables, the results gave trip attraction model $\mathrm{Tj}$ in equation (2) and Chi-square 927423.

$$
\begin{aligned}
& T_{j}=99483-0.0008 X_{1}+0.005 X_{2}-0.008 \\
& X_{3}-0.0003 X_{4}-0.004 X_{5}-6163 X_{6}
\end{aligned}
$$

\section{Trip Atrraction Considering Geographical Weighting based on The Concentric Model}

The concentric model in Surabaya is shown in Fig. 4. The city activity centres consist of zones 19, 20, 26, 27, and 28, while the rests are peripheries.

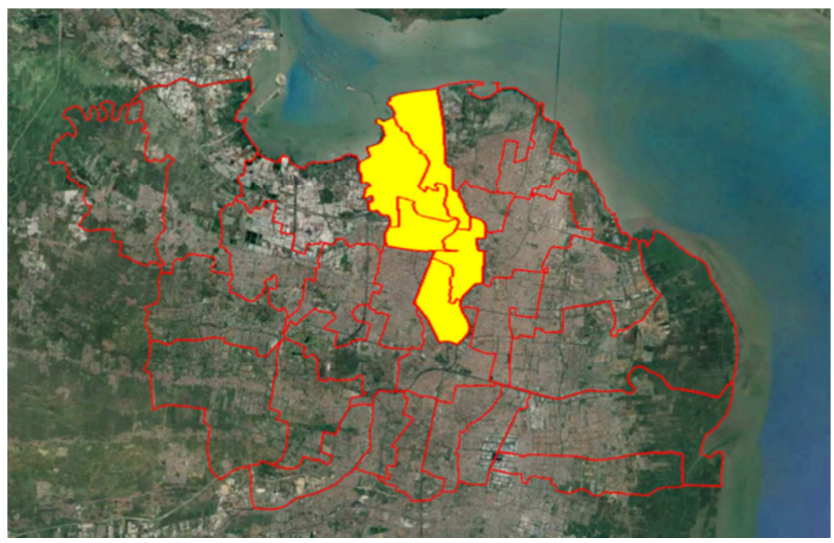

Fig. 4 Subdistrict close to the centre of concentric model (background [7])

Incorporating spatial variables into 2 groups of the concentric model's geographical types produces trip attraction model Tjk in equation (3) and Chi-square value 876407 . However, this is only slightly better than equation (2) and is not influenced by distance

\section{Trip Atraction Considering Geographical Weighting based on Sector Model}

When the sector model is applied in Surabaya as in Fig. 5, sectoral activity centres consist of zones $3,4,8,9,10,11,12$, $15,17,19,20,26,27$, and 28 , while the rests are peripheries. The sector centres are north-south and east-west corridors of the city.

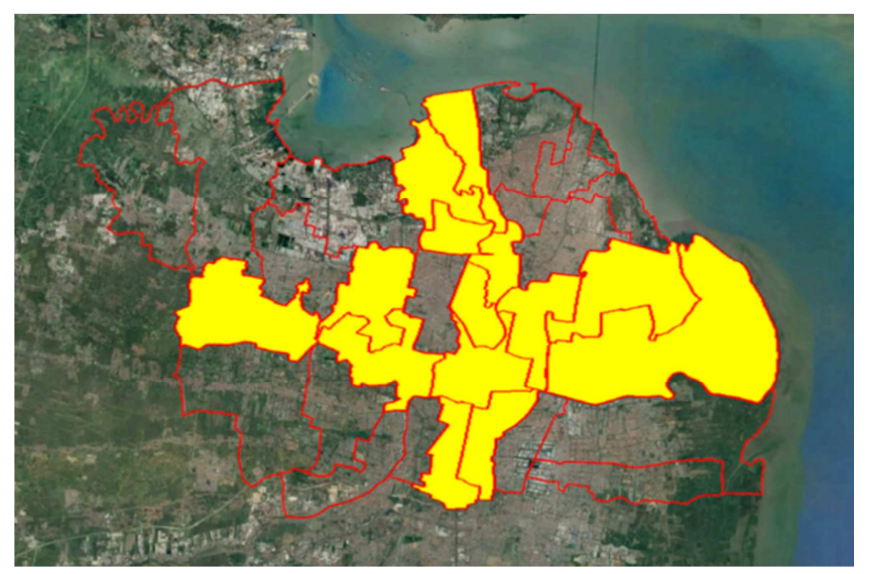

Fig. 5 Subdistricts close to centres of sector model (background [7])

Incorporating spatial variables into 2 groups of geographical types of sector model produces trip attraction model Tjk in equation (4), with a Chi-square value of 660445. There is a significant increase in accuracy compared to equation (2), and the trip attraction is influenced by distance. 
TABLE I

ZONAL AND SPATIAL DATA OF SURABAyA

\begin{tabular}{|c|c|c|c|c|c|c|c|}
\hline Zone & Subdistrict & $\mathbf{X 1}$ & $\mathbf{X} 2$ & $\mathbf{X 3}$ & $\mathbf{X 4}$ & X5 & X6 \\
\hline 1 & Karangpilang & 187165 & 25683 & 30650 & 1435104 & 0 & 8.5 \\
\hline 2 & Jambangan & 47776 & 63690 & 188235 & 15243 & 0 & 7.8 \\
\hline 3 & Gayungan & 65004 & 1240443 & 196615 & 33026 & 267540 & 7.8 \\
\hline 4 & Wonocolo & 244091 & 149529 & 985400 & 46381 & 0 & 7.1 \\
\hline 5 & Tenggilismejoyo & 111889 & 66842 & 4488 & 928360 & 0 & 8.0 \\
\hline 6 & Gununganyar & 187920 & 115892 & 812641 & 255668 & 0 & 10.0 \\
\hline 7 & Rungkut & 583389 & 62377 & 442046 & 1095619 & 0 & 9.2 \\
\hline 8 & Sukolilo & 170910 & 199743 & 815684 & 29417 & 0 & 9.6 \\
\hline 9 & Mulyorejo & 456550 & 266418 & 982854 & 47621 & 72580 & 9.0 \\
\hline 10 & Gubeng & 871625 & 335172 & 442791 & 19856 & 4360 & 6.3 \\
\hline 11 & Wonokromo & 440979 & 491538 & 840876 & 287959 & 577642 & 6.2 \\
\hline 12 & Dukuhpakis & 557747 & 295566 & 112399 & 92821 & 396998 & 6.3 \\
\hline 13 & Wiyung & 231995 & 70577 & 106809 & 62892 & 0 & 7.8 \\
\hline 14 & Lakarsantri & 102284 & 46577 & 110349 & 20833 & 0 & 9.3 \\
\hline 15 & Sambikerep & 169035 & 36261 & 37104 & 82374 & 481746 & 9.1 \\
\hline 16 & Tandes & 170470 & 221312 & 248205 & 2541091 & 0 & 8.5 \\
\hline 17 & Sukomanunggal & 395264 & 300619 & 200617 & 446864 & 0 & 6.7 \\
\hline 18 & Sawahan & 380251 & 189063 & 45068 & 34439 & 0 & 5.8 \\
\hline 19 & Tegalsari & 301442 & 212668 & 22011 & 19148 & 404520 & 5.7 \\
\hline 20 & Genteng & 517050 & 1717379 & 140320 & 7965 & 396545 & 6.0 \\
\hline 21 & Tambaksari & 322547 & 193996 & 133236 & 207642 & 151735 & 7.2 \\
\hline 22 & Kenjeran & 56600 & 49240 & 137939 & 333258 & 0 & 8.8 \\
\hline 23 & Bulak & 0 & 3264 & 45524 & 129611 & 0 & 9.5 \\
\hline 24 & Simokerto & 380554 & 38563 & 30540 & 36233 & 137010 & 6.9 \\
\hline 25 & Semampir & 515547 & 1435461 & 242511 & 1947882 & 0 & 8.0 \\
\hline 26 & Pabeancantikan & 625193 & 311300 & 65627 & 482532 & 546728 & 7.6 \\
\hline 27 & Bubutan & 1510162 & 354711 & 78034 & 164073 & 189510 & 6.1 \\
\hline 28 & Krembangan & 150001 & 1405630 & 106113 & 123574 & 107279 & 7.1 \\
\hline 29 & Asemrowo & 46111 & 454513 & 25959 & 8393014 & 0 & 6.4 \\
\hline 30 & Benowo & 78667 & 9400 & 62492 & 1061936 & 0 & 10.1 \\
\hline 31 & Pakal & 88394 & 7974 & 68980 & 173891 & 0 & 12.2 \\
\hline
\end{tabular}

Where:

$\mathrm{Tj}=$ Daily trip attraction in 2011(trips) [11]

$\mathrm{X} 1=$ floor area of street shopping place $(\mathrm{m} 2)$

$\mathrm{X} 2=$ floor area of office and bank (m2)

$\mathrm{X} 3=$ floor area of the school and university $(\mathrm{m} 2)$

$\mathrm{X} 4=$ floor area of industry and warehouse (m2)

$\mathrm{X} 5=$ floor area of mall and shopping centre $(\mathrm{m} 2)$

$\mathrm{X} 6=$ Average distance to residential $(\mathrm{km})$

$$
T_{j k}=\frac{\left(A_{k} \cdot X_{1 j k}+B_{k} \cdot X_{2 j k}+C_{k} \cdot X_{3 j k}+D_{k} \cdot X_{4 j k}+E_{k} \cdot X_{5 j k}\right)}{\left(3.65 \cdot X_{6 j}^{0}\right)}
$$

for $\mathrm{k}=1$ (concentric centres) $\mathrm{k}=2$ (periphery)
$\mathrm{A} 1=0.03 ; \mathrm{B} 1=0.006 ; \mathrm{C} 1=0.21 ; \mathrm{D} 1=0 ; \mathrm{E} 1=0.5$

$\mathrm{A} 2=0.36 ; \mathrm{B} 2=0.08 ; \mathrm{C} 2=0.16 ; \mathrm{D} 2=0.08 ; \mathrm{E} 2=0$ 


$$
T_{j k}=\frac{\left(A_{k} \cdot X_{1 j k}+B_{k} \cdot X_{2 j k}+C_{k} \cdot X_{3 j k}+D_{k} \cdot X_{4 j k}+E_{k} \cdot X_{5 j k}\right)}{\left(4.34 \cdot X_{6 j}^{0.46}\right)}
$$

$$
\begin{array}{cl}
\text { for } \mathrm{k}=1 \text { (sector centres) } & \mathrm{A} 1=0.23 ; \mathrm{B} 1=0.18 ; \mathrm{C} 1=0.38 ; \mathrm{D} 1=0.15 ; \mathrm{E} 1=0.12 \\
\mathrm{k}=2 \text { (periphery) } & \mathrm{A} 2=1.31 ; \mathrm{B} 2=0 ; \mathrm{C} 2=1.61 ; \mathrm{D} 2=0.12 ; \mathrm{E} 2=2.22
\end{array}
$$

Trip Atrraction Considering Geographical Weighting based on Multiple-nuclei Model. The Multiple-nuclei model in Surabaya is shown in Fig. 6, in which multi-nuclei centres consist of zones 1, 3, 6, 7, 9, 11, 15, 19, 20, 26, 27, 28, and 29 , while the rests are peripheries.

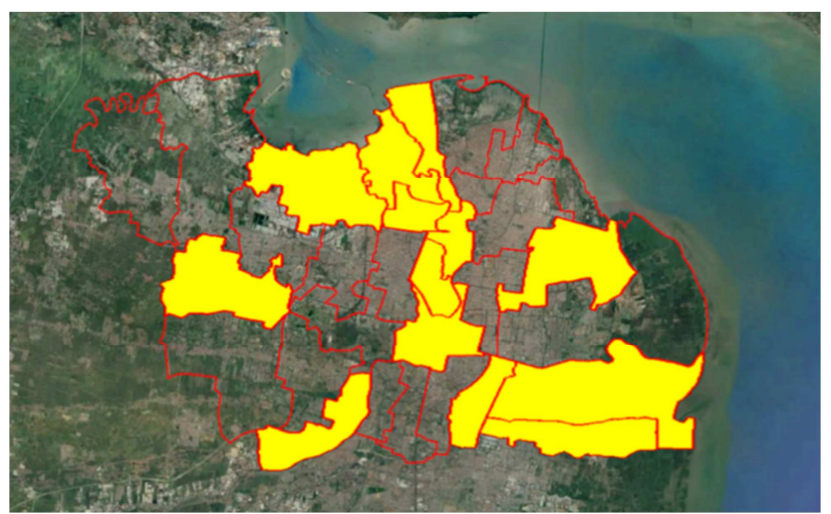

Fig. 6 Subdistrict close to centres of multiple nuclei model (background [7])
- Geographical group 1 is sub-districts in the city centre of the concentric model,

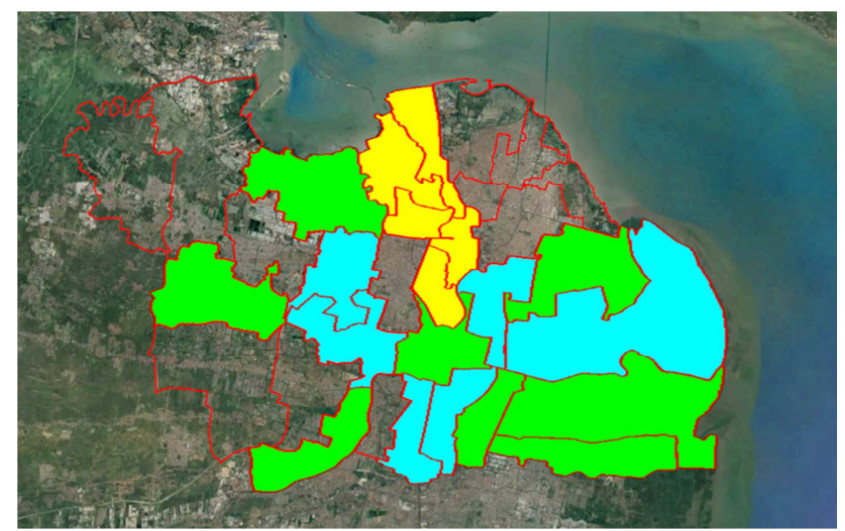

Fig. 7 Subdistrict with 4 geographical groups (background [7])

- Geographical group 2 is sub-districts in the corridors of the sector model, excluding the traditional concentric centres and sub-district having malls,

$$
T_{j k}=\frac{\left(A_{k} \cdot X_{1 j k}+B_{k} \cdot X_{2 j k}+C_{k} \cdot X_{3 j k}+D_{k} \cdot X_{4 j k}+E_{k} \cdot X_{5 j k}\right)}{\left(6.02 \cdot X_{6 j}^{0}\right)}
$$

$$
\begin{aligned}
& \text { for } \mathrm{k}=1 \text { (concentric centres) } \mathrm{A} 1=0.19 ; \mathrm{B} 1=0.08 ; \mathrm{C} 1=0.11 ; \mathrm{D} 1=0.07 ; \mathrm{E} 1=0.41 \\
& \mathrm{k}=2 \text { (periphery) } \mathrm{A} 2=0.67 ; \mathrm{B} 2=0 ; \mathrm{C} 2=0.31 ; \mathrm{D} 2=0.23 ; \mathrm{E} 2=1.47 \\
& T_{j k}=\frac{\left(A_{k} \cdot X_{1 j k}+B_{k} \cdot X_{2 j k}+C_{k} \cdot X_{3 j k}+D_{k} \cdot X_{4 j k}+E_{k} \cdot X_{5 j k}\right)}{\left(3.10 \cdot X_{6 j}^{0.74}\right)} \\
& \text { for } \mathrm{k}=1 \text { (centrum) } \mathrm{A} 1=0.13 ; \mathrm{B} 1=0.04 ; \mathrm{C} 1=0.68 ; \mathrm{D} 1=0 ; \mathrm{E} 1=1.62 \\
& \mathrm{k}=2 \text { (corridors) } \mathrm{A} 2=0.0002 ; \mathrm{B} 2=0.61 ; \mathrm{C} 2=0.61 ; \mathrm{D} 2=0.50 ; \mathrm{E} 2=0 \\
& \mathrm{k}=3 \text { (satellites) } \mathrm{A} 3=1.65 ; \mathrm{B} 3=0 ; \mathrm{C} 3=0 ; \mathrm{D} 3=0.10 ; \mathrm{E} 3=0 \\
& \mathrm{k}=4 \text { (peripheries) } \mathrm{A} 4=1.5 ; \mathrm{B} 4=0 ; \mathrm{C} 4=3.45 ; \mathrm{D} 4=0.25 ; \mathrm{E} 4=0
\end{aligned}
$$

The weighting of 2 groups of geographical types using the multi-nuclei model produces trip attraction model $\mathrm{Tjk}$ in equation (5) and a Chi-square value of 592442, which is even better than the equation (4).

\section{E. A trip Attraction Using 4 Geographical Groups Weighting}

Exploring geographical weighting and spatial as enrichment of Trip Attraction model is achieved by adding geographical group using city structure knowledge and considering the distance from the city centre to residentials.

There are 4 groups, as is shown in Figure 7, categorized as follows:
- Geographical group 3 is sub-districts having malls and industrials of the multiple-nuclei model, and

- Geographical group 4 is sub-districts in the periphery area.

The weighting of 4 groups of geographical types, including centre, corridor, satellite and periphery, and distance between centres and residential, produce trip attraction model in equation (6), with relatively higher accuracy, indicated by a Chi-square value of 367657 .

\section{F. Resume of Trip Attraction Using Geographical Weighting}

The study resume is shown in Table 2. It indicates that the chi-square value is better when there is more geographical 
grouping. Unlike the gravity type trip distribution model, this model is strongly theoretical, using the City Structure Model of concentric, sector or multiple-nuclei.

TABLE II

CHI-SQUARE AND BETTERMENT OF ACCURACY

\begin{tabular}{|l|l|l|}
\hline City Centres Assumption & $\begin{array}{l}\text { Chi- } \\
\text { Square }\end{array}$ & $\begin{array}{l}\text { Betterment of } \\
\text { accuracy (\%) }\end{array}$ \\
\hline Not considered & 927423 & 0 \\
\hline Concentric Model & 876407 & 6 \\
\hline Sector Model & 660445 & 29 \\
\hline Multiple-nuclei Model & 592442 & 36 \\
\hline $\begin{array}{l}\text { Centrum, Corridors, } \\
\text { Satellites }\end{array}$ & 367657 & 60 \\
\hline
\end{tabular}

Accuracy is increased when geographic weighting is applied, or the spatial variable is used. Combining geographic weighting and spatial variables to the model produce better chi-square. Grouping of zones into 4 groups based on the degree of activities as centrum, corridors, satellites, and peripheries increases accuracy than 2 groups of centre and peripheries.

Using a geographical grouping of 4 groups and spatial position to the city centre using the sector model produces the highest accuracy. Chi-square reduction without geographic waiting increases the accuracy by $60 \%$.

\section{CONCLUSIONS}

Using the same data based on the city centre concept, the Trip Attraction Model involving geographical weighting produces different accuracy degrees. Among several models, a geographical grouping of 4 city centre groups yields the best accuracy. This method produces an accuracy increase of up to $60 \%$ (Surabaya case). Furthermore, it is better than the conventional method since the data is digitized and measured from Google Earth. However, due to the digitizing and measuring process's time-consuming nature, highly trained labour should be incorporated into this method.

\section{REFERENCES}

[1] P. R. Stopher, and A. H. Meyburg, "Urban Transportation Modelling and Planning", Lexington Book, D.C. Heath and Company, 1975. Available: https://trid.trb.org/view/61685

[2] J. W. Dickey, W. J. Diewald, A. G. Hobeika, C. J. Hurst, N. T. Stephens, R. C. Stuart, and R. G. Walker, Metropolitan Transportation Planning. Taylor \& Francis, 1983.

[3] https://www.google.com/intl/id/earth/versions/\#earth-pro

[4] PG. Forecasting Trip Attraction Based On Commercial Land Use Characteristics. International Journal of Research in Engineering and Technology. eSAT Publishing House; 2013 Sep 25;02(09):4719. Available from: http://dx.doi.org/10.15623/ijret.2013.0209072

[5] Arliansyah J, Hartono Y. Trip Attraction Model Using Radial Basis Function Neural Networks. Procedia Engineering. Elsevier BV; 2015;125:445-51. Available http://dx.doi.org/10.1016/j.proeng.2015.11.117
[6] Google earth V 7.3.3.7699. (May 7, 2020). Indonesia, $1^{\circ} 24$ ' 34.16" $\mathrm{S}, 119^{\circ} 29^{\prime} 03.44^{\prime \prime} \mathrm{E}$, Eye alt $4493.76 \mathrm{~km}$. Image Landsat / Copernicus @ 2020 Google, US Dept os Ftate Geographer, Data SIO, NOAA, U.S. Navy. NGA. GEBCO. Available: http://www.earth.google.com [December, 14, 2015].

[7] Google earth V 7.3.3.7699. (May 7, 2020). Surabaya, Indonesia, $7^{\circ}$ 17 '01.78" S, $112^{\circ} 44^{\prime} 56.67 ”$ E, Eye alt $33.91 \mathrm{~km}$. Image (C) 2020 Terrametrics, (C) 2020 Google, Image (C) 2020 Maxar Technologies Data SIO, NOAA, U.S. Navy. NGA. GEBCO. Available: http://www.earth.google.com [April, 9, 2020].

[8] Soemardiono B, Rachmawati M, Ardianta DA, Nugroho S. Spatial Analysis of Urban Dense Area in Developing Criteria Design Based on People Participation: A Case Study of Kembang Jepun, Surabaya. Geographia Technica. Asociatia Geograhia Technica; 2019 Mar 29;14(special):13-21. Available from: http://dx.doi.org/10.21163/gt_2019.141.14

[9] Næss P, Strand A, Wolday F, Stefansdottir H. Residential location, commuting and non-work travel in two urban areas of different size and with different center structures. Progress in Planning. Elsevier BV; 2019 Feb;128:1-36. Available from: http://dx.doi.org/10.1016/j.progress.2017.10.002

[10] Dinas Perhubungan Kota Surabaya, "Studi Pengembangan Model Transportasi di Kota Surabaya", Laporan Akhir, 2011.

[11] R. E. Park, and E. W. Burgess, The City, University of Chicago Press pp. 47-62, 1925. ISBN 9780226148199.

[12] H. Hoyt, The Structure and Growth of Residential Neighborhoods in American Cities, Washington, Federal Housing Administration, 1939.

[13] Harris CD, Ullman EL. The Nature of Cities. The ANNALS of the American Academy of Political and Social Science. SAGE Publications; 1945 Nov;242(1):7-17. Available from: http://dx.doi.org/10.1177/000271624524200103

[14] Sefrus T, Priyanto S, Parikesit D, Dewanti, Irawan MZ. Kualanamu International Airport: Current Development toward Aerotropolis. International Journal on Advanced Science, Engineering and Information Technology. Insight Society; 2020 Mar 28;10(2):866. Available from: http://dx.doi.org/10.18517/ijaseit.10.2.7999

[15] https://tcx-converter.software.informer.com/2.0/

[16] Brunsdon C, Fotheringham AS, Charlton ME. Geographically Weighted Regression: A Method for Exploring Spatial Nonstationarity. Geographical Analysis. Wiley; 2010 Sep 3;28(4):281-98. Available from: http://dx.doi.org/10.1111/j.15384632.1996.tb00936.x

[17] Yang H, Zhang Y, Zhong L, Zhang X, Ling Z. Exploring spatial variation of bike sharing trip production and attraction: A study based on Chicago's Divvy system. Applied Geography. Elsevier BV; 2020 Feb;115:102130. Available from: http://dx.doi.org/10.1016/j.apgeog.2019.102130.

[18] Hyman GM. The Calibration of Trip Distribution Models. Environment and Planning A: Economy and Space. SAGE Publications; 1969 Jun;1(1):105-12. Available from: http://dx.doi.org/10.1068/a010105

[19] Lasdon LS, Fox RL, Ratner MW. Nonlinear optimization using the generalized reduced gradient method. Revue française d'automatique, informatique, recherche opérationnelle Recherche opérationnelle. EDP Sciences; 1974;8(V3):73-103. Available from: http://dx.doi.org/10.1051/ro/197408v300731

[20] Smith DP, Hutchinson BG. Goodness of fit statistics for trip distribution models. Transportation Research Part A: General. Elsevier BV; 1981 Jul;15(4):295-303. Available from: http://dx.doi.org/10.1016/0191-2607(81)90011-x

[21] E. Emmerson, "Accuracy of Trip Forecasts Based on Simple Distribution Models", TRRL Laboratory Report 1044, Crowthorne, UK, 1982. Available: https://trid.trb.org/view/181616 